\title{
Medical Treatment of Cushing's Syndrome: Adrenal-Blocking Drugs and Ketaconazole
}

\author{
Richard A. Feelders Leo J. Hofland Wouter W. de Herder \\ Department of Internal Medicine, Endocrine Section, Erasmus Medical Center, Rotterdam, The Netherlands
}

\section{Key Words}

Cushing's syndrome $\cdot$ Medical treatment $\cdot$ Adrenal blocking drugs

\begin{abstract}
Cushing's syndrome is associated with serious morbidity and increased mortality. Irrespective of its cause, i.e. a pituitary adenoma, ectopic ACTH production or an adrenal neoplasia, Cushing's syndrome is primarily treated surgically. However, when surgery is unsuccessful or contraindicated, medical therapy is needed to treat hypercortisolism. The spectrum of available drugs includes adrenal-blocking agents, neuromodulatory drugs and glucocorticoid receptor antagonists. Adrenal blocking drugs suppress adrenal cortisol production via inhibition of steroidogenic enzymes. Ketoconazole and metyrapone are most frequently used for this purpose, but chronic treatment with these drugs can be limited by side effects like hepatotoxicity (ketoconazole) and increased androgen and mineralocorticoid production (metyrapone). Etomidate can be used to rapidly reverse cortisol excess in patients with acute complications of (severe) hypercortisolism like psychosis. In Cushing's disease, combination therapy with drugs that target the corticotropic adenoma, i.e. the universal somatostatin analogue pasireotide and/or the dopamine agonist cabergoline, and low-dose ketoconazole seems a rational approach to achieve biochemical control.

Copyright $\odot 2010$ S. Karger AG, Basel
\end{abstract}

\section{Introduction}

Cushing's syndrome (CS) is traditionally divided into adrenocorticotropin (ACTH)-dependent CS and ACTHindependent CS. ACTH-dependent CS is usually caused by a corticotropic pituitary adenoma and rarely by ectopic ACTH production by a neuroendocrine tumor. ACTH-independent CS is caused by an adrenal adenoma, adrenal carcinoma or bilateral adrenal hyperplasia. At present, surgery is the first-line treatment modality for CS, irrespective of its cause, in order to achieve biochemical cure [1]. However, if surgery fails or is contraindicated, hypercortisolism is treated medically. Medical treatment of CS can be divided into three groups: (1) adrenal-blocking drugs; (2) neuromodulatory drugs, e.g. somatostatin analogs, dopamine agonists, and (3) glucocorticoid receptor-blocking agents, e.g. mifepristone [1, 2]. Among these drugs, adrenal-blocking drugs are widely used and their indications, efficacy and adverse event profiles are discussed in this overview.

\section{Indications for Medical Therapy}

Depending on the cause of CS various indications exist for medical therapy to treat hypercortisolism (table 1).

\section{KARGER}

Fax +4161306 1234

E-Mail karger@karger.ch

www.karger.com
(C) 2010 S. Karger AG, Basel

0028-3835/10/0925-0111\$26.00/0

Accessible online at:

www.karger.com/nen
Richard A. Feelders

Department of Internal Medicine, Erasmus Medical Center Rotterdam

's Gravendijkwal 230

NL-3015 CE Rotterdam (The Netherlands)

Tel. +31 10704 0704, Fax +31 10703 3726, E-Mail r.feelders@erasmusmc.nl 
Table 1. Possible indications for medical therapy for Cushing's syndrome

\begin{tabular}{ll}
$\begin{array}{l}\text { Type of Cushing's } \\
\text { syndrome }\end{array}$ & Indication \\
\hline $\begin{array}{l}\text { Pituitary-dependent } \\
\text { Cushing's syndrome }\end{array}$ & $\begin{array}{l}\text { Pretreatment before pituitary surgery } \\
\text { Acute complications of hypercortisolism } \\
\text { Persistent hypercortisolism after pituitary } \\
\text { surgery } \\
\text { Nonvisible adenomas } \\
\text { High operation risk }\end{array}$ \\
\hline Ectopic ACTH & $\begin{array}{l}\text { Acute complications of hypercortisolism } \\
\text { syndrome }\end{array}$ \\
& Unresectable or metastasized tumors \\
\hline High operation risk \\
syndrenal Cushing's & Acute complications of hypercortisolism \\
& $\begin{array}{l}\text { Unresectable or metastasized adrenal } \\
\text { carcinoma } \\
\text { Ectopic hormone receptor expression }\end{array}$ \\
& High operation risk \\
\hline
\end{tabular}

\section{Pituitary-Dependent CS}

In patients with pituitary-dependent CS, medical therapy is applied in several centers as pretreatment before pituitary surgery in order to decrease perioperative complications due to hypercortisolism. With transsphenoidal adenomectomy, biochemical remission is achieved in $60-80 \%$ of patients, in particular in patients with microadenomas $[1,3,4]$. However, success rates are considerably lower in patients with macroadenomas, invisible adenomas or adenomas with unfavorable localization such as the parasellar region. In addition, in the long term, recurrences do occur in up to $20 \%$ of patients [1, $3-5]$. These patients are frequently treated with radiotherapy to induce definitive remission. However, radiotherapy has a slow onset of action, resulting in exposure of patients to the deteriorating effects of cortisol excess during several years [6].

Persistent hypercortisolism is associated with increased morbidity and mortality. Apart from the clinical features of CS that severely impair quality of life, uncontrolled hypercortisolism increases the risk on infectious, thromboembolic and cardiovascular disease [7]. Mortality is increased in CS, in particular in those patients with persistent hypercortisolism [8]. This underscores the importance of reversal of cortisol excess in CS. Therefore, indications of medical therapy for pituitary-dependent CS include pre-surgical treatment, although controlled studies on efficacy are lacking, persistent or recurrent hy- percortisolism after pituitary surgery and to overcome the period after which radiotherapy becomes effective. Primary medical therapy can be considered in patients with a nonvisible adenoma and in patients with a high operation risk due to high age and/or significant comorbidity.

\section{Ectopic ACTH Syndrome}

Cushing's syndrome caused by ectopic ACTH production is frequently accompanied by acute complications of hypercortisolism due to the severity of cortisol excess. This includes symptoms like hypertension, hypokalemia and edema due to mineralocorticoid effects of high cortisol levels, psychosis and (opportunistic) infections. In these conditions, hypercortisolism needs to be treated rapidly, either medically or by bilateral adrenalectomy [7].

Patients with metastatic disease and ectopic ACTH production cannot be cured surgically and in these patients medical therapy, or ultimately bi-aderenalectomy, is indicated to treat hypercortisolism, next to tumor-directed therapy, i.e. chemo- or radiotherapy.

\section{Adrenal Cushing's Syndrome}

Adrenal causes of CS in which medical therapy can be indicated are bilateral adrenal hyperplasia and adrenal carcinoma. In patients with bilateral adrenal hyperplasia, cortisol production is frequently regulated by ectopic hormone receptor expression, e.g. vasopressin receptor, luteinizing hormone receptor, and in some patients cortisol production can be normalized by blockade of the ectopic receptor or by inhibition of the production of its endogenous ligand [9]. Otherwise, these patients are usually treated by bilateral adrenalectomy.

Patients with unresectable or metastasized cortisol-producing adrenal carcinoma are treated with cortisol-lowering agents next to tumor-directed therapy to treat symptoms and prevent complications of cortisol excess.

\section{Adrenal-Blocking Drugs}

Several adrenal-blocking drugs can be used to treat hypercortisolism in CS (table 2) which are discussed below. However, it should be noted that none of these drugs has officially been approved for the treatment of CS. In addition, most studies that report on the therapeutic effects of these drugs show retrospective data in small patient numbers. 
Table 2. Adrenal-blocking drugs

\begin{tabular}{llcll}
\hline Drug & Mechanism & Dose & Efficacy & Adverse events \\
\hline Mitotane & adrenolytic effects & $0.5-8 \mathrm{~g} / \mathrm{day}$ & $\pm 80 \%$ & neurological, gastrointestinal \\
Etomidate & inhibition of SE & $0.03-0.3 \mathrm{mg} / \mathrm{kg} / \mathrm{h}$ & unknown & hypocortisolism \\
Metyrapone & inhibition of SE & $0.5-6 \mathrm{~g} / \mathrm{day}$ & $\pm 75 \%$ & hypertension, acne, hirsutism \\
Ketoconazole & inhibition of SE & $400-1,200 \mathrm{mg} /$ day & $\pm 70 \%$ & hepatotoxicity, gastrointestinal, hypogonadism \\
\hline
\end{tabular}

$\mathrm{SE}=$ Steroidogenic enzymes.

\section{Aminoglutethimide}

Aminoglutethimide is an anticonvulsant agent that also suppresses adrenal steroid production by inhibition of cholesterol side-chain cleavage and the steroidogenic enzymes $11 \beta$-hydroxylase and 18-hydroxylase [2]. Aminoglutethimide has been used to decrease cortisol production in CS in the past, although with an unfavorable adverse event profile, but at present, the drug is no longer available.

\section{Mitotane}

Mitotane, o, $\mathrm{p}^{\prime}-\mathrm{DDD}$, is an adrenolytic agent that is used primarily to treat adrenal carcinoma. Apart from suppression of cell growth, mitotane inhibits cholesterol side-chain cleavage and $11 \beta$-hydroxylase resulting in decreased cortisol production [10]. Mitotane, in a dose up to $6 \mathrm{~g} /$ day, can be effective in the treatment of ACTHdependent CS [11]; however, it has a slow onset of action and serum levels of mitotane should be monitored to achieve therapeutic concentrations and to prevent toxicity. Mitotane has serious gastrointestinal, neurological and hepatic side effects. In addition, mitotane can induce adrenal insufficiency, hypercholesterolemia and alterations in hormone-binding globulins [2]. Considering these adverse events, mitotane is not very suitable for chronic treatment of hypercortisolism in CS except for cortisol-producing adrenal carcinomas.

\section{Etomidate}

The anesthetic drug etomidate, an imidazole derivative, suppresses steroidogenesis by inhibition of cholesterol side-chain cleavage and the enzymes 17-hydroxylase, 11ß-hydroxylase and C17-20 lyase [12]. Etodimate has a rapid onset of action and is particularly useful in patients with acute and/or life threatening complications of CS, e.g. psychosis and severe hypertension, in an ICU setting [13]. Generally, these are patients with ectopic ACTH production and overwhelming cortisol produc- tion, but cases with patients with Cushing's disease have also been reported [2]. Etomidate is given parenterally at a dose of between 0.03 and $0.3 \mathrm{mg} / \mathrm{kg} / \mathrm{h} \mathrm{[1]}$.

\section{Metyrapone}

Metyrapone blocks the last step of cortisol synthesis by inhibition of $11 \beta$-hydroxylase [14] and can decrease cortisol production in patients with adrenal tumors, ectopic ACTH production and Cushing's disease [15]. Effective dosages of metyrapone vary between 500 and $6,000 \mathrm{mg} /$ day $[1,2]$. Patients should be carefully monitored for the development of hypocortisolism. A potential disadvantage of metyrapone treatment of Cushing's disease is the occurrence of a compensatory increase in ACTH production resulting from a decrease in cortisolmediated negative feedback on the corticotropic adenoma [15]. This, in turn, can lead to an increased adrenal production of cortisol, but also of androgens and mineralocorticoid precursors. Although an escape of cortisol levels is infrequently observed during metyrapone treatment, hirsutism, acne and mineralocorticoid effects (hypertension, hypokalemia and edema) can limit prolonged treatment with metyrapone $[1,2,15]$. In several countries metyrapone is not available commercially.

\section{Ketoconazole}

Ketoconazole, an imidazole derivative, is an antifungal agent that, in higher dosages, reduces adrenal steroid production via inhibition of multiple steroidogenic enzymes, e.g. 11 $\beta$-hydroxylase, 17-hydroxylase and 18-hydroxylase [16, 17]. In a dose range between 400 and 1,200 $\mathrm{mg} /$ day, ketoconazole can decrease cortisol production in patients with CS of various etiology $[1,2,17-20]$. The major side effect of ketoconazole is hepatotoxicity and liver function should be monitored carefully during treatment. In addition, ketoconazole can cause hypogonadism in men and gastrointestinal complaints. No prospective studies with ketoconazole monotherapy have been per- 
formed. Therefore, efficacy data are only available from retrospective studies, mostly with small patient numbers. Recently, Castinetti et al. [20] reported that ketoconazole induced biochemical remission in $50 \%$ of patients with Cushing's disease. Taking all studies together, ketoconazole has an efficacy of approximately 70\% [20]. Studies are, however, difficult to compare with respect to patient selection, treatment duration, pretreatment with radiotherapy, etc.

Apart from adrenal blocking effects, ketoconazole may also have direct effects on corticotropic tumor cells in patients with Cushing's disease. Stalla et al. [21] have shown that ketoconazole inhibits both basal and CRFstimulated ACTH production by rat anterior pituitary cells. We have recently found that ketoconazole suppresses ACTH production by both mouse AtT20 and human corticotropic tumor cells. In addition, ketoconazole inhibited cell growth, in part by the induction of apoptosis. Interestingly, the effects on ACTH secretion and cell growth were potentiated by the universal somatostatin analog pasireotide [unpubl. results]. These effects may explain the absence of a compensatory rise in ACTH levels in patients with Cushing's disease during prolonged treatment with ketoconazole [18], which contrasts to the observed ACTH increase during chronic treatment with metyrapone [15].

\section{Combination Therapy}

Currently, no medical monotherapy is available for the treatment of CS that couples a maximum efficacy to a minimum of toxicity. In addition, for Cushing's disease, the most prevalent form of CS, there is a clear need for tumor-directed therapy. Somatostatin receptor subtype (sst) 5 and dopamine receptor subtype $2\left(\mathrm{D}_{2}\right)$ are potential therapeutic targets on corticotropic tumor cells [22]. In a short-term trial with pasireotide, a novel somatostatin analog with high affinity for $\mathrm{sst}_{1,2,3}$ and $\mathrm{sst}_{5}$, normalization of urinary free cortisol (UFC) levels was achieved in $17 \%$ of patients [23]. Treatment with the $\mathrm{D}_{2}$ agonist cabergoline resulted in long-term control in $40 \%$ of patients [24]. We recently performed a study with pasireotide mono- or combination therapy with cabergoline and lowdose ketoconazole during 80 days [25]. Seventeen patients with Cushing's disease were treated in a stepwise approach with pasireotide as initial treatment modality which was extended with cabergoline and ketoconazole after 4 and 8 weeks, respectively, according to UFC levels. With this approach, biochemical remission was achieved in $90 \%$ of patients, i.e. in $29 \%(5 / 17)$ with pasireotide monotherapy, in an additional $24 \%$ (4/17) by addition of cabergoline to pasireotide and in another $35 \%(6 / 17)$ by triple therapy with pasireotide, cabergoline and ketoconazole. Pivonello et al. [24] also found beneficial effects of the addition of low-dose ketoconazole in patients who were partially responsive to cabergoline [unpubl. results]. Combination therapy with drugs that have additive or potentiating effects seems a rational approach to treat CS and may allow for lower dosages of drugs with serious adverse events like ketoconazole.

\section{Conclusions}

Medical therapy has an important role in the treatment of CS when surgery is unsuccessful or not indicated. The increased morbidity and mortality of uncontrolled CS highlights the importance of rapid reversal of hypercortisolism. Inhibition of adrenal steroid synthesis with adrenal-blocking drugs can be effective and in this respect metyrapone and ketoconazole are most frequently used. Long-term use of these drugs can, however, be limited by side effects. Etomidate can be useful in patients with acute complications of severe hypercortisolism. In Cushing's disease, combination therapy of (low-dose) ketoconazole with pasireotide and/or cabergoline is a promising treatment modality. Prospective, long-term studies are needed to establish efficacy, in terms of reversal of increased morbidity and mortality, and safety of medical therapy for CS.

\section{Disclosure Statement}

R.A. Feelders is consultant for Novartis. W.W. de Herder is consultant for Novartis and Ipsen.

References

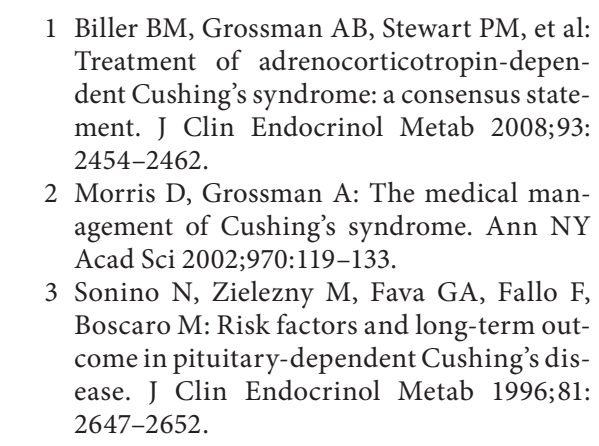

Feelders/Hofland/de Herder 
4 Atkinson AB, Kennedy A, Wiggam MI, McCance DR, Sheridan B: Long-term remission rates after pituitary surgery for Cushing's disease: the need for long-term surveillance. Clin Endocrinol (Oxf) 2005;63:549-559.

5 Patil CG, Prevedello DM, Lad SP, Vance ML, Thorner MO, Katznelson L, Laws ER Jr: Late recurrences of Cushing's disease after initial successful transsphenoidal surgery. J Clin Endocrinol Metab 2008;93:358-362.

6 Estrada J, Boronat M, Mielgo M, Magallon R, Millan I, Diez S, Lucas T, Barcelo B: The long-term outcome of pituitary irradiation after unsuccessful transsphenoidal surgery in Cushing's disease. N Engl J Med 1997;336: 172-177.

$\checkmark 7$ Newell-Price J, Bertagna X, Grossman AB, Nieman LK: Cushing's syndrome. Lancet 2006;367:1605-1617.

$\checkmark 8$ Dekkers OM, Biermasz NR, Pereira AM, Roelfsema F, van Aken MO, Voormolen JH, Romijn JA: Mortality in patients treated for Cushing's disease is increased, compared with patients treated for nonfunctioning pituitary macroadenoma. J Clin Endocrinol Metab 2007;92:976-981.

$\checkmark 9$ Lacroix A: ACTH-independent macronodular adrenal hyperplasia. Best Pract Res Clin Endocrinol Metab 2009;23:245-259.

${ }_{10}$ Young RB, Bryson MJ, Sweat ML, Street JC: Complexing of DDT and o,p'DDD with adrenal cytochrome P-450 hydroxylating systems. J Steroid Biochem 1973;4:585-591.

- 11 Luton JP, Mahoudeau JA, Bouchard P, Thieblot P, Hautecouverture M, Simon D, Laudat $\mathrm{MH}$, Touitou Y, Bricaire H: Treatment of Cushing's disease by o,p'DDD. Survey of 62 cases. N Engl J Med 1979;300:459-464.
12 Lamberts SW, Bons EG, Bruining HA, de Jong FH: Differential effects of the imidazole derivatives etomidate, ketoconazole and miconazole and of metyrapone on the secretion of cortisol and its precursors by human adrenocortical cells. J Pharmacol Exp Ther 1987;240:259-264.

13 Drake WM, Perry LA, Hinds CJ, Lowe DG, Reznek RH, Besser GM: Emergency and prolonged use of intravenous etomidate to control hypercortisolemia in a patient with Cushing's syndrome and peritonitis. J Clin Endocrinol Metab 1998;83:3542-3544.

14 Carballeira A, Fishman LM, Jacobi JD: Dual sites of inhibition by metyrapone of human adrenal steroidogenesis: correlation of in vivo and in vitro studies. J Clin Endocrinol Metab 1976;42:687-695.

15 Verhelst JA, Trainer PJ, Howlett TA, Perry L, Rees LH, Grossman AB, Wass JA, Besser GM: Short and long-term responses to metyrapone in the medical management of 91 patients with Cushing's syndrome. Clin Endocrinol (Oxf) 1991;35:169-178.

16 Engelhardt D, Weber MM, Miksch T, Abedinpour F, Jaspers C: The influence of ketoconazole on human adrenal steroidogenesis: incubation studies with tissue slices. Clin Endocrinol (Oxf) 1991;35:163-168.

17 Sonino N: The use of ketoconazole as an inhibitor of steroid production. N Engl J Med 1987;317:812-818

18 Sonino N, Boscaro M, Paoletta A, Mantero F, Ziliotto D: Ketoconazole treatment in Cushing's syndrome: experience in 34 patients. Clin Endocrinol (Oxf) 1991;35:347-352.

$\checkmark 19$ Tabarin A, Navarranne A, Guerin J, Corcuff JB, Parneix M, Roger P: Use of ketoconazole in the treatment of Cushing's disease and ectopic ACTH syndrome. Clin Endocrinol (Oxf) 1991;34:63-69.

20 Castinetti F, Morange I, Jaquet P, ConteDevolx B, Brue T: Ketoconazole revisited: a preoperative or postoperative treatment in Cushing's disease. Eur J Endocrinol 2008; 158:91-99.
21 Stalla GK, Stalla J, Huber M, Loeffler JP, Hollt V, von Werder K, Muller OA: Ketoconazole inhibits corticotropic cell function in vitro. Endocrinology 1988;122:618-623.

22 de Bruin C, Pereira AM, Feelders RA, Romijn JA, Roelfsema F, Sprij-Mooij DM, van Aken MO, van der Lelij AJ, de Herder WW, Lamberts SW, Hofland LJ: Coexpression of dopamine and somatostatin receptor subtypes in corticotroph adenomas. J Clin Endocrinol Metab 2009;94:1118-1124.

23 Boscaro M, Ludlam WH, Atkinson B, Glusman JE, Petersenn S, Reincke M, Snyder P, Tabarin A, Biller BM, Findling J, Melmed $\mathrm{S}$, Darby $\mathrm{CH}, \mathrm{Hu} \mathrm{K}$, Wang Y, Freda PU, Grossman AB, Frohman LA, Bertherat J: Treatment of pituitary-dependent Cushing's disease with the multireceptor ligand somatostatin analog pasireotide (SOM230): a multicenter, phase II trial. J Clin Endocrinol Metab 2009;94:115-122.

24 Pivonello R, De Martino MC, Cappabianca P, De Leo M, Faggiano A, Lombardi G, Hofland LJ, Lamberts SW, Colao A: The medical treatment of Cushing's disease: effectiveness of chronic treatment with the dopamine agonist cabergoline in patients unsuccessfully treated by surgery. J Clin Endocrinol Metab 2009;94:223-230.

-25 Feelders RA, de Bruin C, Pereira AM, Romijn JA, Netea-Maier RT, Hermus AR, Zelissen PM, de Jong FH, van der Lely AJ, de Herder WW, Hofland LJ, Lamberts SW: Stepwise medical treatment of Cushing's disease with pasireotide mono- or combination therapy with cabergoline and low-dose ketoconazole. N Engl J Med 2010;362:1846-1848. 